\title{
Dissolution and the Making of the English Literary Canon: The Catalogues of Leland and Bale
}

\section{TREVOR ROSS}

\section{M}

odern canon-formation, by this definition, is inaugurated in England at the moment of most intense destruction, the Dissolution of the Monasteries in the first decades of the Reformation. The unlikely pioneers in this case were the antiquaries John Leland and John Bale, who, in the massive bio-bibliographical catalogues they compiled in the 1540 s and $1550 \mathrm{~s}$, produced the first full-scale objectifications of the canon of British letters. I say "unlikely," because both Leland and Bale were hardly moderns, and were very much concerned to argue for the instrumental value of the literature of the past. Sadly for them and for learning in England, the destruction was of such a scale that it simply overwhelmed their arguments, as well as the antiquarians themselves. Bale wrote that he was moved to tears at the sight of the destruction: "thys is highly to be lamented, of all them that hath a naturall loue to their contrey.... That in turnynge ouer of ye superstycyouse monasteryes, so lytle respecte was had to theyr lybraryes for the sauegarde of those noble \& precyouse monumentes." 3 And Leland, who went mad before he could complete his work, lamented how English books were being stolen and their glory unjustly appropriated by foreign scholars: "the Germans perceiving our desidiousness and negligence, do send daily young scholars hither, that spoileth them, and cutteth them out of libraries, returning home and putting them abroad as monuments of their own country." 4

The catalogues that these antiquaries eventually assembled are haunted by the Dissolution. One of the main functions of these works, and the source of their enduring value for later bibliographers, is to provide a documentary record of as many dispersed items as possible, which explains the antiquaries' overriding concern both for accuracy and comprehensiveness. ${ }^{5}$ But the Dissolution also haunts these catalogues as a noticeable absence: nowhere in 
these works do Leland and Bale make statements, like those I have just quoted, declaring their regret over the destruction that followed in the wake of the suppression of the abbeys. The above statements, and others like them, appear in the antiquaries' private letters, or in Bale's preface to his edition of Leland's New Year's address of $1546 / 7$ to Henry VIII. ${ }^{6}$ These catalogues trace a map of dispersal, as Leland and Bale try to keep track of the many rare items they came accross during their researches, but the causes of this dispersal are not discussed. The antiquaries' compelling silence on this matter was for them a difficult trade-off, for the established authority to whom they addressed their appeal was the very same authority, the Tudor Court, that had initiated the Dissolution in the mid-1530s. ${ }^{7}$ It was also the very same authority that had for a time enlisted Bale as an anti-clerical propagandist, and that had granted Leland his famous commission "to make a search after England's antiquities." 8 The Court, through its tightly organized network of patronage, exercised full control over the national culture. There was no other possible authority the antiquaries could turn to.

Leland and Bale both acknowledged that they were working within a long tradition of medieval cataloguers dating back to St. Jerome. ${ }^{9}$ Their immediate inspiration was the work of the Continental bibliographers Johannes Trithemius and Conrad Gesner, whose exhaustive indexes of classical and patristic auctores proved both exceptionally valuable and widely popular within Europe's burgeoning print culture. ${ }^{10}$ The English antiquaries openly borrowed the format of Trithemius's Liber de Scriptoribus Ecclesiasticis (1494) as the model for the entries in their catalogues: an annotated list of works prefaced by a brief life of the author. But what Leland and Bale ultimately produced were no mere booklists. Bale's catalogues, the 1548 Summarium and the much-expanded second edition, the Catalogus of 1557-59, just as much as Leland's (assembled in the $1530 \mathrm{~s}$ and early $1540 \mathrm{~s}$, and referred to extensively by Bale, but not published until 1709,) differed from earlier bibliographies in that the urgency of the situation, the possible loss of England's literary heritage, impelled the antiquaries to bolster the aura of their canons with a number of imperialistic and religious myths. ${ }^{11}$ Refurbishing the old writings through such allegorizing commentary, they hoped, would signal the ideological necessity of preserving the British literary canon in its entirety, as a harmonious whole. The dispersal of the libraries was indication enough that, outside the cloisters, the reasons for having a learned tradition were not self-evident. What they come up with, then, are polemics for British letters, bibliographies animated by the sense that the writings they record may already be lost. The desperate tone of the polemics is a reflection of the marginal status of antiquarianism in a rhetorical culture, where 
the value of any activity involving literary texts is measured in terms of its utility in the present; saving the old books merely for the sake of learning would not have seemed to Leland and Bale a very persuasive argument. More specifically, the polemics are of interest because the context of the Dissolution has rendered acute the task of resolving the central problem in all canon-formation, that of defining how it is the writings of the distant past retain their value in change. In remaining silent on the Dissolution, on the troubling fact that the event involved the deliberate and authorized actions of their contemporaries in rejecting their past, the antiquaries suppress the temporality of their own endeavours. As a consequence, their polemical claims for the productive value of the endangered writings are uttered without any sure sense of an economy wherein such claims might be considered meaningful. The canons they therefore construct are harmonious, expansive, and almost utterly without modernity.

Leland and Bale mythologize their nation's literary history because they are unwilling to confront directly the politics of Dissolution. Both antiquaries elsewhere pledge their support for Henry's reformist policies. In a late unpublished tract, the Antiphilarchia, Leland affirms his undying loyalty to the king, and even credits him with inaugurating antiquarian research into the "independent" origins of the English Church. Bale, one of the Reformation's most prominent controversialists, loudly applauded "the moste lawfull ouerthrow of the sodometrouse Abbeyes and Fryeryes." "Fyrst," he explained, "for so much as they were the professed souldyours of Antichrist, \& next to that, for so muche as they were moste execrable lyuers [sic]. For these causes, I must confesse them most iustly suppressed." 12 Yet Bale also made clear his view that the king's commissioners had been reckless in carrying out the suppression: "would I haue wyshed ... that the profytable corne had not so unaduysedly and ungodly peryshed wyth the unprofytable chaffe, nor the wholsome herbes with the unwholsome wedes."13

Leland was rather more reluctant than Bale to offer criticisms of the suppression, perhaps because, unlike Bale, he was not simply committed to the goal of Reformation but felt a strong personal allegiance to Henry VIII. Evidence suggests that Leland acted as Henry's scout in acquiring selected items for the Royal Library. ${ }^{14}$ Leland also voiced admiration for the New Learning that had come to be associated with the king. ${ }^{15}$ But the ascendancy of the New Learning created a situation where the universities did not discourage the spoliation of medieval documents. As Bale noted, the schools were "not all clere in this detestable fact." 16 In a letter dated 12 September 1535 , Cromwell's most ruthless henchman, Richard Layton, proudly reports 


\section{0 / Renaissance and Reformation}

that he had seen the works of Duns Scotus "banished" from Oxford, the "leaves of Dun" left to blow in the wind or used as "blawnsherres" (scaresheets) to frighten away the deer. ${ }^{17}$ For Leland, torn between his love of antiquities and his devotion to his master and all that he represented, it was an impossible situation. James P. Carley speculates that Leland "was unable to get a perspective on his conflicting loyalties or to find a philosophy which might reconcile the two." 18 Whatever the case, Leland refused to assign blame to any of his countrymen or to link the destruction to the policy of Dissolution.

The antiquaries are equally ambivalent about iconoclasm, the impetus for much of the destruction. Bale rightly notes that a good part of the wastage was due to the avarice of the nobility, who, having taken possession of the suppressed houses, abused their contents or sold them off for profit. These opportunistic lords, says Bale, "reserued of those lybrarye bokes, some to serue theyr iakes, some to scoure theyr candelstyckes, \& some to rubbe their bootes. Some they solde to the grossers and sope sellers, \& some they sent ouer see to ye bokebynders, not in small nombre, but at tymes whole shyppes full." ${ }^{19}$ But Bale also admits that some of the violence may be attributed to "men godly mynded," who, in their iconoclastic zeal, laid waste indiscriminately to all they could get their hands on in the abbeys. ${ }^{20}$ His "declaracyons" appended to Leland's "New Year's Gift" are meant in part as a plea to the English not to emulate the harmful "fury or frantycke madnesse of the Anabaptistes" and other fanatical groups. ${ }^{21}$ Yet Bale himself is impassioned in his condemnation of Catholic "idolatry" and image-making, and seems quite happy to allow the mutilation of books he dislikes: "Of the byshop of Romes lawes, decrees[,] decretals, extrauagantes, clementines and other suche dregges of the deuyll, yea of Heytesburyes sophysmes, Porphyryes uniuersals, Aristotles olde logyckes and Dunses dyuynyte, wyth other lowly legerdemaynes, and frutes of the bottomlesses pytte, had leaped out of our libraries, and so become couerynges for bokes comminge from the foren nacyons, we might wele haue ben therwith contented." 22 Leland, likewise, is known to have defaced a tablet in York Minster that purportedly identified an English king as having taken "this kingdom of the Pope by tribute to hold of the Church of Rome."23

Presumably Leland and Bale have no difficulty with the notion of iconoclasm because they share the Protestant belief in the separation of word and image. But that separation is not always clear-cut. Many books, such as service-books, were often targets of the violence not for any images they may have contained but for the doctrines they expressed. In addition, an increasing number of Protestant authors were discovering the utility of illuminating their texts with woodcuts and engravings: the image, it was believed, was not idolatrous if it served the printed 
word. ${ }^{24}$ The first edition of Bale's catalogue contains laudatory woodcuts of the author and of Wyclif, the hero of Bale's narrative. Bale's inclusion of these woodcuts anticipates the work of later Protestant polemicists who turn this iconographic canon-making into a rather sumptuous art. Bale himself is among the Reformation worthies included in one of the most popular of these portrait galleries, Henry Holland's Heroologia (1620).

Given their ambivalence toward the political, doctrinal and emotional dimensions of Dissolution, Leland and Bale are hard-pressed to come up with convincing arguments for preserving the old books. Both make conventional appeals to patriotic sentiment by asserting that their antiquarian efforts will add "honour to this realm." 25 Yet their patriotism is qualified by the knowledge that the dispersal of England's literary heritage has seriously undermined their nation's reputation among Europe's intellectual élites. Bale wonders aloud how badly it looks upon England "to haue it noysed abroade, that we are despysers of lernynge." 26 An undeclared function of their catalogues-written in Latin for a European audience, and containing no mention of the Dissolution-is to divert foreign attention away from the destruction. Such propaganda, Leland tells Henry, may help "the old glory of your renoumed Britaine to reflorish through the worlde." 27

However effective this attempt at damage control may be within the international community, it does not respond to the more pressing need to counter the indifference and outright hostility for letters still-prevalent at home. Though Leland and Bale disagree over how best to defend individual authors, their arguments on behalf of the literary tradition as a whole rely on three related sets of allegorizing myths: myths of cultural origins, myths of empire, and myths about the continuity of Protestant thought in England. Concern over their nation's low reputation in the world may underlie the antiquaries' willingness to embrace the first set of myths, those having to do with Britain's pre-history. Leland's catalogue opens with several entries describing the civilizing influence of bards and druids, while both editions of Bale's work contain an elaborate fiction about Britain's colonization, complete with a epic genealogy that extends from Adam and Seth, to Samothes Gigas (Homer's brother, no less) and "Bardus," the bringer of poetry and song, to the Trojan Brutus, from whose name was derived "Britain." 28 These imaginative accounts of England's origins are a rejoinder to similar propaganda made on behalf of other nations, such as a number of French claims that had declared the erudition of Gallic bards superior even to Roman learning. ${ }^{29}$

The myth-making is equally a holdover from an earlier period when the Tudor monarchy had sought to strengthen his shaky claim to the throne by 
declaring direct descent from Arthur and other semi-legendary figures of the English past. By linking this royal genealogy to England's literary tradition, the antiquaries are clearly hoping to appeal to Tudor anxieties, and to save the tradition by upholding the legitimizing power of antiquities. In the same spirit, the antiquaries promise that their catalogues will establish England's reputation as an imperial power, which is the common theme of their second set of myths. The grandeur of the antiquaries' imperial vision is reflected in the size of their catalogues. Bale, in his attempt to include every figure who could conceivably have some connection with British letters, seems to have lost sight of the original aim of preservation, with the result that the final, bloated version of his catalogue contains some 1400 entries, many of which, like those for Merlin and Pope Joan, have little to do with saving old manuscripts and much to do with portraying England as an elect nation. With a little under 600 entries, Leland's catalogue is shorter yet no less far-reaching, as Leland expends a good deal of energy trying to refute other nations' claims on writers, many of them legendary, who he believes are quite properly British. His catalogue of writers was originally intended as the first part of a much larger and systematic survey of Britain's land, nobility and history, a project whose ideological tenor Leland was only happy to make clear: just as Charlemagne had among his treasures silver engravings of Rome and Constantinople, Leland tells his master, "so shall your Maiestie haue thys your worlde and impery of Englande so sett fourthe in a quadrate table of silver." 30

The third set of myths represents the most powerful argument for preservation the antiquaries have to offer, and the point of most profound disagreement between the two. Both assert that their research is intended to provide evidence of the persistence of reformist thought and activity in England. The old writings are worth preserving, they maintain, because some long-concealed verities of primitive Christianity may yet be found among them. Says Bale to his patrons, "ye might parauenture se many unknowne wonders." 31 Leland, likewise, assures King Henry that his efforts will bring "full manye thynges to lyght, as concernynge the usurped autoryte of the Byshopp of Rome and hys complyces, to the manyfest and uyolent derogacyon of kyngely dygnyte." ${ }^{2}$ The Antiphilarchia notwithstanding, however, Leland's commitment to reformist ideals is not as intense as Bale's, and seems less a reflection of deep religious convictions than an extension of his loyalty to Henry. Bale even expressed dismay at how Leland had treated many works in his catalogue "with no discrimination between doctrines or testing of spirits, and the fact that evil things are taken as holy." 33 
In contrast to Leland, Bale believed strongly in the need to recover and publicize suppressed work's of radical theology, though his first priority in his catalogue is to legitimize the Reformation by retracing England's history so as to confirm its unique destiny as a continuator of the early Church. ${ }^{34} \mathrm{Bale}$ is among the first English exponents of a powerful Protestant eschatology that rejects the Augustinian separation of divine from worldly existence, and sees instead the possibility of human history coinciding at some future time with the re-emergence of a true Christianity. J. G. A. Pocock has described some of the features of this apocalypticism and has noted how it often posits a historical line of divinely-inspired authors: "God has pronounced, through the mouths of prophets, certain words in time; the occasions of these pronouncements, together with other happenings to which they refer, constitute a series of divine acts in past time; we believe that these acts were performed by believing the authors and the words they have relayed to us. ... All is logos, and logos is a system of communications through time." 35 The goal Bale sets for himself in his catalogue is to identify this logos from among all the writings ever produced in England, and to write the narrative of its history: "what continuaunce, what darkeninges, what decayes, what falle, and what rayse againe." $11^{36}$

The antiquaries' ideological differences translate into two distinct approaches to canon-making. Where Leland erects a pantheon to honour king and empire, Bale desires the enabling continuities of a tradition. And where Leland is apt to lavish praise indiscriminately, Bale styles himself a discerning judge of what he calls England's "elected heritage." 37 Yet both antiquaries are confronted with the same problem, one that must inevitably be considered in any attempt to claim for the texts of the past the power to transcend their historical origins and to survive the test of time. For Leland and Bale, this problem is not simply one of defending the enduring value of the old books in the face of their widespread destruction. It is equally a problem of representing this living value, the timeless modernity of literary works, while at the same time relating each of these works to a particular historical context, to the occasions of their pronouncements, and to the life and times of the author. In essence, the problem is one of reconciling literary history, with its emphasis on change and historical specificity, with the anti-historicism of canon-formation. ${ }^{38}$ This dialectic of permanence and change is obscured somewhat by the medieval form of the biographical catalogue, which recognizes important individual accomplishments without necessarily situating these in a historical narrative. The antiquaries, for reasons that have to do with their divergent personal motives for preserving the old books, are nonetheless concerned to identify patterns of change in their catalogues, whether this 


\section{4 / Renaissance and Reformation}

change involves the concept of human agency, the use of periodization, or a narrative of decline and rebirth. Yet, in a rhetorical culture, to call attention to historical change in this way cannot but heighten the sense that the books belong to the past and are best forgotten. It becomes incumbent on the antiquaries to suggest how these writings retain value in altered circumstances, including the circumstances of Dissolution, the one context Leland and Bale feel impelled to suppress in their narratives.

It has been argued that Leland's interest in antiquities predates the Dissolution, and develops out of his early acquaintance with Continental humanist scholars. ${ }^{39}$ Certainly Leland has absorbed the codes of humanist polemic and rhetorical culture by the time he sets about defending his nation's canonical literature. In the often quoted opening to his "New Year's Gift," Leland informs Henry that he is in the midst of fulfilling his commission to deliver "the monumentes of auncyent wryters ... out of deadly darkenesse to lyuelye lyght." 40 Light, for Leland as for all humanists, signifies eloquence. His task, as he sees it, is to enliven England's sense of its own past by rescuing its letters and chronicles from the "darkness" of medieval expression. The lives of English kings and poets, he maintains, have been "hitherto sore obscured, bothe for lacke of empryntynge of such workes as laye secretely in comers. ... And also because men of eloquence hath not enterprised, to set them fourth in a floryshynge style."41 Leland's idealization of eloquence suggests how much closer in spirit his catalogue is to Petrarch's biographies of famous men than to the booklists of St. Jerome. The bibliographical import of Leland's catalogue is secondary to the Petrarchan goal of overcoming contemporary ignorance of the glories and personages of the distant past. As Leland suggests at the end of his defense of King Arthur, the triumph of antiquarianism will come when "at lengthe (those same most thicke mistie cloudes in deede of ignorance beeing shaken off, \& vtterly dashed aside) the light of British Antiquitie with displayed beames farre and wide shall shine forth." 42

Leland's use of these luminary metaphors differs in one respect from Petrarch's. The latter's valorization of a radiant eloquence versus a medieval obscurity corresponded to a deliberate periodization of history, a symmetry of illustrious ancients and barbarous moderns. ${ }^{43}$ Such periodization is unhelpful to Leland, as he is trying to exalt not the works of the ancients, but those of the very moderns whose inelegant style he maligns. Leland nonetheless finds the codes of renaissance light and medieval dark appealing for the clarity, the styles of certainty, they offer, even if their use entails periodizing away a large chunk of recent English literary history. His researches, he tells Henry, will "open this wyndow, that the lyght shal be seane, so long, ye is to 
say, by ye space of a whole thousand yeares stopped up." 44 Leland's heavy reliance on such discriminatory language indicates the degree to which he is steeped in rhetorical culture and, as well, the degree to which such thinking cannot help him to deal seriously with historical change and contingency. Leland's florid rhetoric suggests that his evaluative certainties are largely emotional..$^{45}$ This raises the question of what, if anything, does Leland find of value in the old writings. In his "New Year's Gift," Leland writes as though the antiquities themselves were not so important as the general project of antiquarianism. Leland's self-service is perhaps understandable, his "Gift" being a progress report to the king in which Leland is expected to do little more than to outline his research and to say how his efforts will add to the king's majesty. Yet it remains unclear whether Leland's interest in antiquities involves anything other than emotion.

Leland's belief that the writings of the English past constitute enduring monuments of learning stems from his fervent patriotism but equally from a concern his own poetry, which he wrote throughout his career. Leland's love of antiquities carries with it a high emotional investment, as he must prove their lastingness to confirm the immortalizing power of his own verse. Leland's self-service in this respect is no worse than that of earlier poets, though Bale says he found his colleague's quest for authorial self-determination regrettable: "I muche do feare it that he was vaynegloryouse, and that he had a poetycall wytt, whyche I lament, for I iudge it one of the chefest thynges that caused hym to fall besydes hys ryghte dyscernynges." 46 Leland's personal stake in sustaining the mythology of authorial fame determines in large measure the nature of his canon, a Parnassus founded on the self-authorizing and secular agency of the scholarpoet; it is, in other words, a canon founded on the conflicting principles of inclusiveness and revisionism. Leland's canon is meant to be all-encompassing in its listing of all identifiably British bookmen, but its operative mythology is that of the Petrarchan laureate whose self-determination and modernity rest on his ability to displace the literary achievements of the recent past. Leland has therefore to show how his canon retains its integrity and value even as the writers he esteems continually strive to surpass their precursors. Perhaps more troubling, any Parnassus, no matter how expansive, must appear to remain meaningful in changing times, or else it will seem a foolish and anachronistic pretension. Thomas M. Greene has described this phenomenon and has suggested that those texts which do appear to last without seeming too dated are those which incorporate an idea of historicity: "to dramatize in art a survival of the past into an altered present, would seem to provide a text with a certain resilience in confronting its own survival." ${ }^{47}$ It is this balance, between affirming the moder- 
nity of literature and insisting on its historicity, which Leland must achieve if his canon-making is to be at all credible.

It is not an easy balance to sustain. A devotee of Chaucer, Leland includes in his entry on the poet three of his own verse compositions, the second of which compares Chaucer to Homer and Virgil yet which states the English poet could not achieve true greatness because he happened not to live in an age as fortuitous to learning as the classical period. ${ }^{48}$ In what, then, does the value of Chaucer's work consist? Leland hesitates in specifying that value. He repeats the commonplace that Chaucer "refined" the vernacular, but for Leland this accomplishment is only important in a historical sense, and does not attest to Chaucer's enduring value as a poet. Leland subscribes to a notion of a "progress of letters," and believes the standard for poetic excellence in the vernacular rests no longer with Chaucer but with Wyatt, whom Leland, in an eulogy on the poet, calls "the stream, light and lightning of eloquence. ${ }^{" 49}$ Leland goes on to compare Chaucer to the classical poets, a canon whose sempiternal authority is incontestable and that therefore offers an example of past values and meanings surviving in change. Leland thinks several of Chaucer's compositions are likely to endure, being equal in merit to the best of the Latins. ${ }^{50}$ But the assertion fails to persuade because Leland has not specified what is of instrumental or, for that matter, intrinsic value in Chaucer's writings, what it is about those writings that will allow them to survive now that a later generation of authors has surpassed the medieval poet's verbal achievement. Chaucer's high standing in the English canon seems unaccountable, but Leland cannot afford to deny the poet his rank or his permanence. The difficulty Leland has created for himself is one of reconciling a desire for a harmonious, fully inclusive and imperishable canon of British letters, with an equally compelling need for evaluative certainty, for prescribing meaningful criteria by which to judge formal and qualitative differences between works, and for persuading his patrons of the worth and utility of his canon as a whole.

In an attempt to reconcile these divergent aims, Leland has recourse to one final rhetorical construct, the discriminating reader. In a sympathetic entry on Gower, Leland again writes contemptuously of the Middle Ages, but adds that the poet's preeminence can yet be recognized by those who are prepared to make allowances for Gower's age:

he cultivated the humanities and labored much in poetry. This is testified to by his poems of which he wrote many in Latin, zealous rather than felicitous in imitating Ovid. That should seem no wonder, especially in a semi-barbarous age. With difficulty even in our so flourishing time can anyone imitate the overflowing beauties of Ovid's poetry. ... Accordingly, we overlook 
certain infelicities in the poems of Gower, and we hold him up as the first refiner of our native language. For before that time the English language lay uncultivated and nearly wholly raw. Nor was there anyone who could write in the vernacular, works suitable for a discriminating reader. Thus the value of his works lies in their careful cultivation, that, the rude weeds stamped out, instead of thistles arise the pliant violet and purple narcissus. ${ }^{51}$

Leland is working hard to transform his Tudor patrons into reflections of himself: his discriminating reader appreciates the desirability of having an extensive literary canon, and his courtly humanist discretion does not disallow him from enjoying works from England's uncultured past. The "discriminating reader" (or, more usually, the "learned reader") is a figure common to the agonistic structures of classical rhetoric, and routinely appears in early critical evaluations of English literature. But there is something peculiar about Leland's use of the figure, something that reveals Leland's own contradictory impulses. In accordance with the dialectical codes of rhetoric, a discriminating reader must be able to discriminate against something, or else his assertions will seem empty. Leland's discriminating reader lacks this Other; he is an unlikely figure who combines humanist sophistication with a predisposition to look with a favourable and uncritical eye upon the works of longdeparted national authors. The only Other Leland can identify is history itself, the medieval context in which the old writings were first produced. Leland's reader dissociates the literature from its semi-barbarous history, plucks the flowers from their surrounding, weedy garden. Such canon-making, in Leland's narrative of cultural rebirth, will benefit an already "so flourishing age" by helping it to emerge from the dark "clouds of ignorance." What Leland is saying finally is that the preservation of the literary past will help to defeat the pernicious influence of the past. Attempting to court the favour of his patrons, Leland is forced to flatter them in their superiority over the very period and literature he is making claims for. The trade-off deprives his canon of any serious claim to modernity, and leaves Leland with little more than emotion to defend his literary tradition.

If Leland's canon is empowered by the antinomic energies of rhetoric, Bale's is secured in the Word. Preserving the old books is a moral duty for Bale. As his vision of history insists on the role of secular life in human spiritual development, he sees the English people as responsible for the eventual re-establishment of a true Church. According to this argument, the English, as an elect race, must believe in the logos of prophecies and promises contained in the writings of their ancestors in order to achieve their salvation. 
And even if these writings do not reveal long-buried divine pronouncements, they may offer indispensable information on the occasions to which the writings of the reformist prophets may refer. Hence, in Bale's view, the English must save their literature to save themselves. When he laments the harm the Dissolution will bring to future generations, he is referring not simply, as Leland might, to England's reputation but to its people's spiritual redemption: "to put our auncient Chronicles, our noble hystoryes, our learned commentaryes \& homelyes upon ye scriptures, to so homely an office of subieccyon \& utter contempte we have both greatly dishonoured our nacyon, and also shewed our selves very wycked to our posteryte." 52

Given his belief in the continuity of British letters, Bale looks more favourably upon medieval literature than does Leland, and shows particular interest in English poetry. He discusses Caedmon and other Anglo-Saxon minstrels, and includes an entry on "Gildas Cambrius," who is reputed to be Britain's first poet, and whose works Bale greatly regrets not having come across in the course of his research: "O that we had now the floryshyng workes of Gildas, surnamed Cambrius, that most noble Poete and Historyane of the Britaines, which wrote in the tyme of kynge Aruiragus, when S. Peter yet preached to the dispersed bretherne."53 The seriousness with which Bale relates the story of Gildas is owing to his theory of history, which is based on a principle of reductive periodization. Bale is predisposed to believe in the actuality of the first-century Gildas for that would mean a British writer had flourished during the period of the primitive church. He is likewise prepared to assume that the late fourteenth-century English poets were sympathetic to reform because they happen to fall into the one "century" that also included Wyclif-“century" being Bale's term for the roughly-chronological groups of one hundred lives that make up each of his chapters. Bale had in fact initially ascribed the authorship of Piers Plowman to Wyclif himself, but later corrected his error in the Catalogus. He reports, as well, that Chaucer, whose canon of works had by this time been enlarged to include the virulently anti-clerical Plowman's Tale, wrote many works "in which he showed his disapproval of that great multitude of mumblers, the monks, of their idleness, their unintelligible prayers, their relics, pilgrimages and ceremonies." 54

As Frank Kermode has suggested, periodization can serve canon-formation to the extent that it may "enable us to package historical data that would otherwise be hopelessly hard to deal with." 55 Such packaging not only facilitates the task of assessing the works of the past but diminishes their alterity and in so doing makes them seem modern, in harmony with contemporary values. In reducing the later fourteenth century into an age of Wyclif, 
Bale turns history into a mirror of his own times, for Wyclif, he believes, is the "morning star" of the Reformation. ${ }^{56}$ Chaucer and Gower become Lollard poets, whose message is as relevant to sixteenth-century Protestants as it was to audiences of their day. ${ }^{57}$ Bale's periodization works in the other direction, too, as Catholic authors are condemned to their benighted "centuries," yet in a sense these authors are equally modernized, since the conflict of the two churches dominates Bale's narrative as a transhistorical phenomenon. There is an apocalyptic dimension, as well, to the way Bale packages the sum of his centuries. While the quality of a work is dependent on the context of its production, the complexion of that context has itself been wholly preordained. Many "famouse and notable workemen," he writes, "wrote in this nacyon from age to age, some wele some yll, accordynge to the dyuerse nature of their times, like as the holy Ghost forejudged of theyr doynges in S. Johanns reuelacion." ${ }^{58}$ Hardly a relativist, Bale nonetheless speaks powerfully of the judgment of history: "what thynge more clerely tryeth the doctrynes of men, what they are, than do their ages or times?"59 Bale transposes Leland's dialectic of light and dark ages into a stark historical drama of warring centuries, where the sole criterion of judgment is the age when a work was first written. Bale's canon is thus marked by radically prescriptive period divisions, yet within each historical period there is perfect harmony.

Such reduction is finally too deterministic even for Bale, who is concerned to show the political courage of those like Wyclif who saw through the sophistry of the Roman Church and brought the "light of truth" to their age. ${ }^{60}$ Just as Protestants of the present age are responsible for ensuring their salvation, so were individual acts of conscience in the past instrumental in helping to bring about reform. However pre-ordained, the Reformation is a historical break realized through human agency and, in particular, through the power of the written word. The theme of Bale's catalogue, much more so than Leland's, is the historical and moral centrality of writing in human affairs. Though Bale is often unclear as to how exactly particular works contributed to the larger history of true Christianity, his theme requires that he pays close attention to the historical specificity of authors and their works: "Their ages are as necessary to be knowne as their doctrynes, and the tytles of their bokes so wele as their manyfest actes, to them that wyl throughly iudge things as they are, \& not be deceiued by colours." 61 As a result, his catalogues juxtapose the seemingly irreconcilable narratives of historicism and providence, authorship and auctoritas; ${ }^{62}$ Bale is faced with much the same problem that worried Leland, the problem of how to write and judge authoritatively about both the uniform and the divergent values of texts from the past. 
Bale's concern to present "things as they are" leads him to reject Leland's call to embellish the English chronicles. On the contrary, Bale argues, the writers of the past should be allowed to speak for themselves in their own words, "For undoubtedly, authoryte it woulde adde unto them, to apere fyrst of all in their owue [sic] simplycyte or natiue colours without bewtie of speche." To make these works available to all English readers, he suggests, is a much more laudable aim than to refurbish them with a florid style that appeals only to a select few. "And," he adds, "for that purpose (I thynke) God hath iu [sic] thys age geuen the noble art of prentynge." 63 If for Leland "light" denotes eloquence, it symbolizes for Bale, as for other Protestant polemicists, the disseminatory and democratizing powers of print. As Bale's friend John Foxe declared, "through the light of printing the world beginneth now to have eyes to see, and heads to judge." ${ }^{64}$ Darkness, according to this scheme, is not medieval inelegance but the widespread illiteracy of a manuscript age. Bale, who spent his final years lobbying for the publication of pre-Reformation manuscripts, including works antithetical to his own thinking, blamed this illiteracy on a papist conspiracy that "hath alwayes ben busied, seking contrary wyse to obscure all thynges, that contayned any veryte necessarye." ${ }^{65}$ Ironically, the coming of the printed book may have added to the prejudice against the aging, tangibly unmodern manuscripts during the period of their wholesale destruction.

The reality of this destruction points to what is missing from Bale's narrative, a coherent account of how literature survives in change. The absence is even more apparent from his commentary on Leland's "Gift," where he repeatedly insists on the existence of "thynges lastyng \& durable" while at the same time loudly deploring their loss. ${ }^{66} \mathrm{Just}$ as a historicist inquiry can never be perfectly accommodated to a providential, harmonizing design, so metaphysical truths can never be fully coextensive with physical contingencies. Bale's transcendent logos is not an image of survival because it fixes value outside of change, beyond the historicity of authors and their works. Though Bale's pleading for political action places him among the humanists as well as the reformers of his age, his theory of change is as absolutist as Alcuin's theodicy. And although his arguments for the continuing utility of past literature provides his canon with an evaluative certainty that Leland's pantheon lacks, his catalogues seem far more obsolescent than his colleague's, very much the productions of a particular time and place. It is this very susceptibility to anachronism that makes Bale's totalizing canon seem even less modern than Leland's unfinished, conflicted pantheon. 
The catalogues of Leland and Bale belonged to possibly the last period when the entire indigenous literary canon could be so boldly "co-opted" on behalf of nationalist or religious propaganda. The strokes could never again be so broad. ${ }^{67}$ The Elizabethan antiquaries, for their part, would not seem as concerned with the role of literature in English cultural history, and considered the literary canon a topic best left to the margins of their texts. ${ }^{68}$ Stow, though he edited Chaucer's works, offered no more than passing references to the English poets in his Chronicles of England (1580), leaving the task of assessing the canon up to his "continuator," Edmund Howes, who contributed a sizable list of writers "such as were most famous, in the high misterie of POESEY: by whose singular paines, and industry, our native language, hath from time to time, beene much refined: and at this time, directly by them, brought to great perfection: and the abuse of time, \& popular absurdities many wayes disciphered, and amended." Howes's register of names is remarkably full, extending from Roger Bacon to George Wither, but the very miscellaneousness of his list points up the inadequacy of his critical generalizations. Unable to spell out why canonical poetry endures, Howes appeals to mystification and platitude, citing poetry's high mystery as well as its more mundane usefulness as a corrective of popular absurdities. And rather than assess the merit of individual works, Howes, a self-styled "gentleman," presents a harmonious canon of authors ranked "according to their priorities," that is, their social class. ${ }^{69}$

Camden, who has many more things to say about British literature, presents a more intriguing contrast to Leland and Bale because it is clear that he struggles with the very problem his predecessors try to avoid, the problem of defending the enduring value of literature while acknowledging the role of historical change. Camden appears to like poetry a great deal, but seems uncertain as to how to deal with it. It is among those subjects treated in the Remains (1605), Camden's topical assortment of what he calls "the rude rubble and out-cast rubbish ... of a greater and more serious worke," the Britannia $(1586) .{ }^{70}$ Under the generic headings of poems, epigrams, "rhythmes" and epitaphs, Camden compiles brief anthologies of mainly Anglo-Latin verse, and prefaces his selection with a short defense of poetry's didactic and pleasure-giving utility. Yet Camden also feels the need to apologize for his selections and claims to offer only "a taste of some of midle age, which was so overcast with darke clouds, or rather thicke fogges of ignorance, that every little sparke of liberall learning seemed wonderfull: so that if sometime you happen of an uncouth word, let the time entreate pardon for it, when as all words have their times." 71

Camden is torn between asserting the timeless values of poetry and making allowances for the different ages and modes of poetic expression. When he 
says that the Latin epigrammatists Neckham and Giraldus Cambrensis "were not inferior" to those of his own period, he is speaking as a critical historian who upholds the merit of forgotten poetry while recognizing the differences between the ages. ${ }^{72}$ But when he states it was Surrey and not Chaucer who "first refined our homly English Poesy," he begins to speak as more a judge than a defender of poets, and makes claims for a particular idea of poetry within a statement about literary history. ${ }^{73}$ That idea finally overwhelms Camden's original presupposition that "all words have their times," and Camden the antiquary gives way to Camden the arbiter elegantiae for all times: "if I would come to our time, what a world could I present to you out of Sir Philipp Sidney, Ed. Spencer, [nine more] ... \& other most pregnant witts of these our times, whom succeeding ages may justly admire."74 It is only by setting history aside, and by ignoring his introductory remarks on the social utility of poetry, that Camden can so positively affirm the contemporary canon's chances of being admired throughout the ages.

The antiquaries' failure to deal conclusively with the question of how the writings of the past survive the test of time illustrates the limitations of rhetorical culture in the face of historical change. These limitations may account for the antiquaries' profound anxiety about the temporality of their own enterprise. Insofar as they record for posterity's sake the lives and works of hundreds of disparate authors, both catalogues can be seen as objectifying the age-old belief that literature holds the keys to memory and immortality, a topos that runs throughout Leland's writing, if not Bale's. But the very act of recording these lives presumes the need for such a register. Were it not for the catalogues, it seems, all of these long-dead authors would be left to oblivion. Leland and Bale were responding to what they perceived to be a crisis, the dispersal of the monastic collections, which they felt threatened to obliterate England's heritage of letters. Their chosen response, massive catalogues of authors, served two purposes: to supply important information on the whereabouts of the dispersed items, and to secure for British letters the protection of fame through the framing of a literary canon. If, as Curtius maintains, canon-formation "serves to safeguard a tradition," "75 then the motive behind canonformation springs from the feeling that a tradition needs this safeguard, that the works of the past are not in themselves immortal, that they are frequently subject to neglect or outright censorship, that all literature, catalogues of authors included, cannot ultimately survive without the help of canon-makers. Though canon-formation may posit the transhistoricism of literature, it is itself a fundamentally historical act, an often political or emotional response to what is perceived to be a situation detrimental to the survival or right appreciation of literary works, or of authorship itself. What Leland and Bale are anxious to preserve are the conditions for all writing, conditions 
that can ensure the continuance of British letters and, in particular, the safeguarding of the very works of Leland and Bale.

There is equally a measure of anxiety in the antiquaries' almost obsessive determination to persuade through the sheer size of their canons. One of the reasons why these directories seem so unlike an assured production like Johnson's Lives of the Poets, which is itself a biographical catalogue of authors, is that there exists the very real sense that Leland and Bale are working in a cultural vacuum, that there is no evaluative community backing up their efforts. It is no wonder that they speak from emotion and desperation. Without any confirmed and widespread positive opinion on their side, they can be assured of nothing, not even an end to the Dissolution. It is thus a sad conclusion to Bale's work that he should see his own library, made up of books salvaged from the Dissolution, sacked and dispersed within five years of the publication of his Summarium. ${ }^{76}$

To be sure, Leland and Bale are trying to generate a consensus of opinion, but therein lies the paradox at the heart of their endeavour. For there is a very real problem of coming to terms with the reality of the Dissolution. In effect, Leland and Bale must simultaneously affirm and deny that reality, its extent and its meaning. On the one hand, Leland and Bale want to make it known that the writings of the past do contain much that is valuable for England's sense of itself as a nation. But that value is itself contingent upon the willingness of the English to define their identity in terms of their history and literature. It therefore becomes the task of these antiquaries to convince their patrons and fellow reformers of the legitimizing power of tradition, and to make them feel that it is in their best interest to honour the nation's literary heritage. "I haue accuratelye celebrated the names," Leland tells King Henry, of "your progenytours," the former rulers, scholars and poets of England whose line is worth commemorating ostensibly because it culminates in Henry's reign. ${ }^{77}$ And yet it was Henry who sanctioned the Dissolution in the first place. Leland mentions neither the sanction nor the Dissolution in his "New Year's Gift," but can only speak mistily of the glory that will come from bringing the monuments to light. ${ }^{78}$ Addressing the English people rather than the king in particular, Bale can afford to be more explicit than Leland in his condemnation of "the malyce or els slouthfull neglygence of thys wycked age, whych is muche geuen to the destruccyon of thynges memorable."79 Yet no matter how hard he tries to persuade contemporaries of the possible consequences of their actions, he cannot account for the manifestation of this wickedness among a generation that has also brought about Reformation. The "dark" conspiracy against letters that is a feature of his own age may well be a direct repercussion of Reformation, but that is 


\section{4 / Renaissance and Reformation}

certainly not something which Bale is prepared to acknowledge, particularly in his catalogue.

On the other hand, what gives these catalogues their urgency, if not their lasting value, is the Dissolution itself. The dispersal of the monastic collections is a great shameful episode in British history, and bitter confirmation of the nation's enduring lowly stature among European countries: "For so lytle estemynge our true Antiquytees, the proude Italyanes have alwayes holden us for a Barbarouse nacyon." 80 The work of the antiquaries is worthwhile because the situation is so bad, the destruction so deplorable. By extension, the worth of the old books is itself magnified by the threat of extinction. The writings of the past are, it seems, no more valuable than at the very moment when they are in danger of becoming scarce. These so-called "monuments" acquire an aura of irreplaceableness and rarity out of contrast with the spectre of destruction and oblivion. Ultimately, the canons of Leland and Bale derive their rhetorical force and seeming harmoniousness less from élitist or religious discriminations than from the very magnitude of the ongoing catastrophe: the greater the number of old writings that can conceivably be lost, the greater the potential shock value. Once the danger of destruction is lessened, however, it becomes harder to dramatize the worth and utility of the old texts, or to see them as constituting a single, uniform literary tradition. Gone are the powerful evaluative certainties that are tenable only in a crisis like the Dissolution. Only when the objective, non-utilitarian value of past writings and past learning is widely accepted will there be a history of literature in England that is not also insisting on the enduring relevance of texts sunk virtually without a trace. And only then, in the eighteenth century, will the catalogues of Leland and Bale begin to receive the serious attention of scholars and critics. An anonymous 1785 redaction of passages from Warton's History of English Poetry is among the first literary histories to see Leland's canon-making as a symbolic act of preservation, and as an unlikely admonition against modern complacency: "When we look into the accounts of the British writers which have been given us by Leland and other biographers, and observe the multitude of persons whom these biographers have rescued from oblivion, together with the praises they have bestowed upon them, ... we are ready to believe that the times preceding the Reformation were much more learned than has usually been imagined." 81

University of Toronto 


\section{Notes}

1. Alcuin's epistles on the raid have been edited by Colin Chase, in Two Alcuin LetterBooks (Toronto: Centre for Medieval Studies, 1975), 50-56.

2. Walter J. Ong is the most notable historian of shift from a "rhetorical" to an "objectivist" culture. See, in particular, his Rhetoric, Romance, and Technology (Ithaca: Cornell University Press, 1971), and Interfaces of the Word (Ithaca: Cornell University Press, 1977). On the shift from "instrumentalist" to "intrinsic" theories of literary value, see E. D. Hirsch, Jr., "Two Traditions of Literary Evaluation," Literary Theory and Criticism, ed. Joseph P. Strelka (Bern: Peter Lang, 1984), 283-298. See also M. H. Abrams's remarks on "pragmatic theories" in the introductory chapter to The Mirror and The Lamp (Oxford: Oxford University Press, 1953), and Abrams's revision of the chapter, as well as his important essay on "Art-as-Such: The Sociology of Modern Aesthetics," in Doing Things with Texts (New York: Norton, 1989), 3-30 and 135-158.

3. John Bale, The laboryouse Journey \& serche of Johan Leylande, for Englandes Antiquitees, ... with declaracyons enlarged (London, 1549; rpt. Amsterdam: Theatrum Orbis Terrarum, 1975), sig. A7v.

4. John Leland, letter to Thomas Cromwell, dated 16 July 1536 , quoted in part in Anthony à Wood, Athenae Oxonienses, ed. Philip Bliss, 3 vols. (London, 1813), 1: col. 198. Wood notes that he saw the original letter "among the papers of state," but it has since been lost.

5. Though these catalogues offer generally reliable information, especially about postConquest writings, their utility for modern scholars has been eclipsed by the antiquaries' notebooks, which contain valuable library references and some tantalizing quoted extracts unobscured by commentary. As James P. Carley notes, "palaeographers and textual historians are more interested in manuscripts Leland saw and where he saw them than in his interpretations of the data contained in them," in "John Leland and the Contents of English Pre-Dissolution Libraries: Glastonbury Abbey," Scriptorium 40 (1986): 108. One of Bale's notebooks has been edited by Reginald Lane Poole and Mary Bateson under the title Index Britanniae Scriptorum, in Anecdota Oxoniensia 9 (Oxford: Clarendon Press, 1902).

6. See notes 2 and 3 above, and Bale's letter to Matthew Parker, dated 30 July 1560 , edited by H. R. Luard in Cambridge Antiquarian Communications 3 (1864-76): 157-73. It is impossible to get even an approximate figure on how many books were destroyed or dispersed, but it is clear that the losses were very heavy. See the articles by C. E. Wright, "The Dispersal of the Monastic Libraries and the Beginnings of Anglo-Saxon Studies. Matthew Parker and his Circle: A Preliminary Study," Transactions of the Cambridge Bibliographical Society 1 (1951): 208-37, and "The Dispersal of the Libraries in the Sixteenth Century," in The English Library before 1700, ed. Francis Wormald and C. E. Wright (London: Athlone Press, 1958), 148-75.

7. My argument here agrees in general terms with Margaret Aston's in her essay "English Ruins and English History: The Dissolution and the Sense of the Past": "The agonizing sight of wholesale destruction spurred people into activity - even those whose Protestant convictions made them wholly endorse the process at large," in Lollards and Reformers: Images and Literacy in Late Medieval Religion (London: Hambledon Press, 1984), 314.

8. Wood 1: col. 198. 


\section{6 / Renaissance and Reformation}

9. There had been previous attempts in England at producing bibliographical records of library contents. In the fourteenth century, a monk at Bury St. Edmunds compiled a catalogue which surveyed the lives and works of 674 authors, "for the use and convenience of students and preachers." See R.H. Rouse, "Bostonus Burienses and the Author of the Catalogus Scriptorum Ecclesiae," Speculum 441 (1966): 471-499. Bale's catalogue includes an entry describing the "Herculean labours" of one Alan of Lynn, a fifteenth-century Carmelite prior who is reputed to have indexed all available copies in England of important medieval works (Illustrium Maioris Britanniae Scriptorum ... Summarium ["Ipswich," i.e. Wesel, 1548], 185). And Bale, before his conversion, wrote a sizable "bio-bibliographical" study of the literature of his fellow Carmelites, the as yet unpublished Anglorum Heliades (1536). On this work, see Leslie P. Fairfield, John Bale, Mythmaker for the English Reformation (West Lafayette, Ind.: Purdue University Press, 1976), 50-53.

10. On the popularity of these booklists, see Elizabeth L. Eisenstein, The Printing Press as an Agent of Change, 2 vols. (Cambridge: Cambridge University Press, 1979), $1: 88-107$.

11. In his New Year's Gift (laboryouse Journey, sig. C7v), Leland indicated that he had given his catalogue the Petrarchan title "De Viris Illustribus," though it would be later retitled as Commentarii de Scriptoribus Britannicis (2 vols., 1709) by the Oxford printer Anthony Hall.

12. Bale, laboryouse Journey, sig. $\mathrm{A} 2 \mathrm{v}, \mathrm{A} 7 \mathrm{v}$.

13. Bale, laboryouse Journey, sig. A7v. Antonia McLean has noted "there is no proof that the state was directly responsible for the loss or destruction of books on a large scale. The monastic libraries were dispersed through government indifference rather than by deliberate intention." Humanism and the Rise of Science in Tudor England (New York: Neale Watson Academic Public., 1972), 90. Yet clearly the policy of Dissolution helped to undermine the entire system of book collecting and preservation that had existed throughout the Middle Ages.

14. On Leland's activities on behalf of the Royal Library, see J. R. Liddell, “' 'Leland's' Lists of Manuscripts in Lincolnshire Monasteries," English Historical Review 54 (1939): 88-95.

15. See Leland's verses on the English New Learning ("a festal crown of men!") in Hoyt H. Hudson, "John Leland's List of Early English Humanists," Huntington Library Quarterly 2 (1939): 301-04.

16. Bale, laboryouse Journey, sig. $\mathrm{B}_{\mathrm{v}}$.

17. In the same letter, Layton also reports that he had helped institute the king's reforms at Oxford by establishing lectures in Greek and Latin to which "every scholar," upon penalty, was required to attend. Reprinted in G. H. Cook, ed., Letters to Cromwell and others on the Suppression of the Monasteries (London: John Baker, 1965), 46.

18. James P. Carley, "John Leland's Cygnea Cantio: A Neglected Tudor River Poem," Humanistica Lovaniensia 32 (1983): 234.

19. Bale, laboryouse Journey, sig. $\mathrm{B}_{\mathrm{r}}$.

20. Bale, laboryouse Journey, sig. G2v.

21. Bale, laboryouse Journey, sig. E8v. 
22. Bale, laboryouse Journey, sig. G3r.

23. Quoted in Sidney Lee's entry for Leland in $D N B$.

24. On this, see Ernest B. Gilman, Iconoclasm and Poetry in the English Reformation: Down Went Dagon (Chicago: University of Chicago Press, 1986), 36-7.

25. Leland, in Wood 1: col. 198.

26. Bale, laboryouse Journey, sig. B2r.

27. Leland, "New Year's Gift," in Bale, laboryouse Journey, sig. D7v.

28. Bale, Summarium 6-8.

29. Herbert Weisinger surveys this contest of bards in "Who Began the Revival of Learning?" Papers of the Michigan Academy of Science, Arts and Letters 30 (1944): 625-638. See also the so-called "Debate of the Heralds," where spokesmen for both England and France boast of their respective nation's glories, canons of learned men and women included. One of Bale's contemporaries, John Coke, fired one of the last shots in this debate, in The Debate between the Heralds of England and France, rptd. with Le Débat des Hérauts D'Armes de France et D'Angleterre, ed. Léopold Pannier and M. Paul Meyer (Paris, 1877).

30. Leland, "New Year's Gift," in Bale, laboryouse Journey, sig. D5. Bale, well aware of the prescription of only four empires in the Book of Daniel, is uneasy with calling Britain an "empire." In his annotations to Leland's "New Year's Gift" (laboryouse Journey, sig. D6. .), he tries to excuse Leland's suggestion that England is an "impery" by appealing to patristic authority; Josephus and other historians, Bale maintains, thought the prescriptions did not apply to England because it was for them another world beyond the sea.

31. Bale, laboryouse Journey, sig. $\mathrm{H} 5$ v.

32. Leland, "New Year's Gift," in Bale, laboryouse Journey, sig. C5v.

33. Bale, manuscript note in his epitome of Leland's De Viris Illustribus, quoted in Fairfield 116.

34. Once the reformers had achieved political power, observes F. Smith Fussner, it became incumbent upon Protestant apologists like Bale "to justify the origins of authority by appealing to history, largely because Protestant churches were not institutionally legitimized by tradition or history in the sense that the Roman Catholic Church was," in Tudor History and the Historians (New York: Basic Books, 1970), 293 n.92.

35. J. G. A. Pocock, Politics, Language and Time: Essays on Political Thought and History (New York: Atheneum, 1971; rpt. Chicago: University of Chicago Press, 1989), 179-80.

36. Bale, The vocacyon of Johan Bale to the bishoprick of Ossorie in Irelande ("Rome," i.e. Wesel, 1553), sig. B3r.

37. Bale, vocacyon, sig. B $7_{\mathrm{r}}$.

38. Lawrence Lipking's contradistinction between "canons and surveys" (or professional evaluation and definition of the arts versus empirical fact-gathering by scholars and men of leisure) does not apply here: the catalogues of Leland and Bale represent the moment just prior to the realization of this split between criticism and antiquarianism (The Ordering of the Arts in Eighteenth-Century England [Princeton: Princeton 
University Press, 1970], 13). Leland and Bale are trying to raise the stock of British literature, and are presenting it for comparison with the literatures of other nations, all within a documentary survey of England's literary history.

39. This view is supported by Joseph M. Levine, who states flatly that the "antiquarian impulse was born of the revival of antiquity," in Humanism and History: Origins of Modern English Historiography (Ithaca: Cornell Univ. Press, 1987), 73. Antonia Gransden offers the counter-argument that "ultimately the alterations which took place in historical writing were less the result of ideas derived from the study of the classics, than of political and religious exigencies," in Historical Writing in England, 2 vols. (London: Routledge \& Kegan Paul, 1974-1982), 2:469.

40. Leland, in Bale, laboryouse Journey, sig. B8 .

41. Leland, in Bale, laboryouse Journey, sig. $\mathrm{C}_{2}-\mathrm{C} 3_{\mathrm{r}}$.

42. Assertio inclytissimi Arturii Regis Britanniae (London, 1544) fol. 37; rpt. in The Famous Historie of Chinon of England by Christopher Middleton, ed. William Edward Mead (London: EETS, 1925) pt. 2:146. Mead also reprints Richard Robinson's 1582 translation of Leland's text, where the quote appears in pt. 2:89-90.

43. See Eisenstein 1:294-8, and Theodor E. Mommsen, "Petrarch's Conception of the 'Dark Ages'," Speculum 17 (1942): 226-242.

44. Leland, "New Year's Gift," in Bale, laboryouse Journey, sig. D7.

45. On Leland writing mainly from emotion, see Herschel Baker, The Race of Time (Toronto: University of Toronto Press, 1967), 91.

46. Bale, laboryouse Journey, sig. B4r.

47. Thomas M. Greene, The Vulnerable Text: Essays on Renaissance Literature (New York: Columbia Univ. Press, 1986), 223. Greene examines how the humanists dealt with the question of how it is that ancient works retain their meaning through change, in The Light in Troy: Imitation and Discovery in Renaissance Poetry (New Haven: Yale University Press, 1982), 4-53.

48. Leland, Commentarii 422.

49. Leland, Naeniae in mortem Thomae Viati equitis incomparibilis (London, 1542), sig. A4v.

50. Leland, Commentarii 421.

51. Leland, Commentarii 428. Quoted from translation given in John H. Fisher, John Gower: Moral Philosopher and Friend of Chaucer (New York: New York University Press, 1964), 14.

52. Bale, laboryouse Journey, sig. G3r.

53. Bale, laboryouse Journey, sig. $\mathrm{F}_{\mathrm{r}}$.

54. Bale, Scriptorum Illustrium maioris Brytanniae ... Catalogus, 2 vols. (Basel, 15571559), 1:526. Quoted from translation given in Caroline F.E. Spurgeon, ed., Five Hundred Years of Chaucer Criticism and Allusion, 1357-1900, 3 vols. (Cambridge: Cambridge University Press, 1925), 3:26. It is worth speculating whether the Reformist booksellers who enlarged Chaucer's canon with anti-clerical tracts were not using Chaucer's canonical authority to shield these tracts from official censorship. Was Chaucer above censorship? "Canterburye tales, Chaucers bokes Gowers bokes" were 
among the few items exempted from prohibition in a 1542/3 "Acte for the Advancement of true Religion and for the Abolishment of the Contrary" (Statute 34 and 35 Henry VIII, quoted in Spurgeon 1:84-5.) Bale's assertions about Chaucer's anti-clericalism are echoed by subsequent polemicists, reaching a peak of outrageousness in Antony Cade's claim that Chaucer was known to call the pope "an idle Lawrell, a Marshall of Hell, a pround, envious, covetous Lucifer, and Antichrist," in A Justification of the Church of England (1630), 63-4.

55. Frank Kermode, History and Value (Oxford: Clarendon Press, 1988), 109.

56. Bale, Summarium, fol. $154 \mathrm{v}$.

57. Bale is not entirely insensitive to literary values and he will, like Leland, occasionally compare the works of the moderns against the standard of the ancients. His entry for Skelton (Catalogus 1:651) deals mainly with the poet's confrontations with the Church, but Bale also stresses the affinities between Skelton's satires and Horace's, and calls the poet another Lucan or Democritus.

58. Bale, laboryouse Journey, sig. $\mathrm{H} 5_{\mathrm{v}}$.

59. Bale, laboryouse Journey, sig. $\mathrm{H} 6_{\mathrm{r}}$.

60. Bale, Summarium, fol. 154v.

61. Bale, laboryouse Journey, sig. $\mathrm{H} 5_{\mathrm{v}}$.

62. As Donald A. Pease has suggested, author and auctor are necessarily opposed. Whereas the long-standing doctrine of auctoritas posited a universal order whose ultimate authority was divine rather than secular, the emergence of authorship in the early modern era represented the self-authorization, or "self-determination" in writing, of the autonomous human subject. See Pease's entry for "Author" in Critical Terms for Literary Study, ed. Frank Lentricchia and Thomas McLaughlin (Chicago: University of Chicago Press, 1990), 105-117.

63. Bale, laboryouse Journey, sig. " $\mathrm{Cv}_{\mathrm{r}-\mathrm{v}}$, , i.e., $\mathrm{C} 3_{\mathrm{r}-\mathrm{v}}$.

64. John Foxe, Acts and Monuments, ed. George Townsend, 8 vols. (London, 1843-1849), $3: 720$.

65. Bale, laboryouse Journey, sig. $\mathrm{F} 6_{\mathrm{r}}$.

66. Bale, laboryouse Journey, sig. F8v.

67. Bale and Leland are by no means the last to produce ideologically-inspired catalogues of authors. The Anglo-Catholic canon, for example, is defended in John Pits's Relationum historicarum de Rebus Anglicis (Paris, 1619). Among the nationalists, Thomas Dempster, in his Historia Ecclesiastical Gentis Scotorum (Bononiae, 1627), and Sir James Ware, in his De Scriptoribus Hiberniae (Dublin, 1639), defend the honour of Scotland and Ireland, respectively.

68. On the antiquaries' relucant acceptance of the Albion myths, see T. D. Kendrick, British Antiquity (London: Methuen, 1950), 99-133.

59. John Stow, The Annales, or Generall Chronicle of England, continued and augmented ... by Edmund Howes (London, 1615), 811.

70. William Camden, Remains Concerning Britain, ed. R.D. Dunn (Toronto: University of Toronto Press, 1984), 3.

71. Camden 288. 
72. Camden 295.

73. Camden 344.

74. Camden 294.

75. Ernst Robert Curtius, European Literature and the Latin Middle Ages, trans. Willard R. Trask (New York: Harper \& Row, 1963), 256.

76. For more on the dispersal of Bale's library, see Honor McCusker, "Books and Manuscripts Formerly in the Possession of John Bale," The Library, 4th ser., 16 (1936): 144-165.

77. Leland, "New Year's Gift," in Bale, laboryouse Journey, sig. D. Nothing reveals more clearly the antiquaries' desire to combine valorization with documentation than this notion of "accurate celebration."

78. Leland refers only very briefly to the destruction in his "Gift": "I haue conserued many good authors, the whych otherwyse had ben lyke to haue peryshed, to no small incommodyte of good letters. Of ye which parte remayne in the most magnificent libraryes of your royall palaces" (in Bale, laboryouse Journey, sig. C2 ${ }_{\mathrm{r}}$.)

79. Bale, laboryouse Journey, sig. D3v.

80. Bale, laboryouse Journey, sig. $\mathrm{C5}_{\mathrm{r}}$.

8I. "A Short View of the State of Knowledge, Literature, and Taste, in this Country, from the Accession of King Edward I to ... Henry IV," New Annual Register for the year 1784 (London, 1785), xii. 